\title{
The Growth of Protestantism in Brazil and Its Impact on Male Earnings, 1970-2000
}

\author{
Joseph E. Potter \\ The University of Texas at Austin \\ joe@prc.utexas.edu \\ Ernesto F. L. Amaral \\ Universidade Federal de Minas Gerais, Brazil \\ eflamaral@gmail.com \\ Robert D. Woodberry \\ National University of Singapore \\ polwrd@nus.edu.sg
}

\begin{abstract}
Protestantism has expanded rapidly in Brazil in recent decades. The question we tackle in this paper is whether Protestantism has had a positive influence on male earnings in this setting, either through its influence on health and productivity, by way of social networks or employer favor and reduced discrimination, or through other mechanisms. We tackle the problem of the selectivity of religious conversion and affiliation using microdata from the Brazilian censuses of 1970, 1980, 1991, and 2000, and analyzing the association between Protestantism and earnings at the group rather than the individual level. Our results show a strong association between the proportion of Protestants in a region, and the earnings of men in one educational group: those with less than five years of education. Upon introducing race into our models, we found that the association between religion and the earnings of less educated men is concentrated in regions in which there is a substantial non-white population. The relationships we have uncovered contribute to the literature on racial inequality and discrimination in Brazil, which to date has given little space to the role of religion in moderating the pernicious effect of race on economic outcomes in Brazil. The substantial association we found between religion and earnings contrasts with much of the research that has been carried out on the influence of religion on earnings in the United States.
\end{abstract}

\section{Keywords}

Protestantism. Religion. Earnings. Brazil.

\section{Acknowledgments}

This research was supported by a grant from the Eunice Kennedy Shriver National Institute of Child Health and Human Development, 5 R24 HD042849 (awarded to the Population Research Center at the University of Texas at Austin), and grants from the Metanexus Institute and the Templeton Foundation (R. D. Woodberry, PI). Address correspondence to Joseph E. Potter, Population Research Center, 305 E. 23rd Street, Stop G1800, Austin, TX 78712-1699; phone: 512-471-8341; E-mail: joe@prc.utexas.edu.

\section{Final publication}

Potter JE, Amaral EFL, Woodberry R. 2014. "The growth of Protestantism in Brazil and its impact on male earnings, 1970-2000.” Social Forces, 93(1): 125-153.

(http://dx.doi.org/10.1093/sf/sou071) 


\section{Introduction}

Protestantism has expanded rapidly in Brazil in recent decades resulting in a substantial religious transformation in a country in which, forty years ago, nearly all citizens were at least nominally Catholic. The churches that have grown the fastest have Pentecostal or neo-Pentecostal roots, such as the Assemblies of God or the Universal Church of the Kingdom of God. When the vibrancy and impact of these Churches are discussed in the popular press, reference is often made to former drunks who, after converting to Pentecostalism, have transformed their lives for the better. A typical description is found in a story filed by Reuters reporter, Todd Benson, shortly before the Pope's visit to Brazil in 2007:

"For years, Ronaldo da Silva's daily routine consisted of drinking himself into a stupor until he passed out on a sidewalk. Now he spends his days praying and singing with hundreds of fellow Christians at the Universal Church of the Kingdom of God in Carapicuiba, a sprawling shantytown on the outskirts of Sao Paulo where Pentecostal congregations are found on just about every block.

'I'd probably be dead or in jail if it weren't for this church,' said da Silva, a 38-yearold former Catholic who claims God cured him of epilepsy and helped him straighten out his life when he converted to Pentecostalism a decade ago.

Conversions like da Silva's are increasingly common all over Brazil, where a boom in evangelical Protestantism is steadily chipping away at the supremacy of the Roman Catholic Church." (http://www.reuters.com/article/idUSN3023920920070503).

In this paper, we seek to assess whether the increase of Protestantism in Brazil has led to an increase in male earnings. If the type of experience described above is indeed widespread, we might expect to find an impact of Protestantism among the least fortunate segments of the population most afflicted by alcohol dependency, binge drinking, and drugs, crime, family break down. Moreover, since Brazilians who identify themselves as having black or brown skin color and Afro-Brazilian descent are especially likely to join Pentecostal churches, the newly converted may be especially prone to have sufffered racial and class discrimination (Burdick 1999; Telles 2004). But if conversion to Protestantism is especially likely to occur among those who have a history of illness or problematic behavior, and who 
have faced the greatest discrimination and deprivation, then even after conversion Protestants might well be no better off than other members of the population even though their personal lot had improved considerably. We tackle the problem of the selectivity of religious conversion and affiliation using microdata from the Brazilian censuses of 1970, 1980, 1991, and 2000, and analyzing the association between Protestantism and earnings at the group rather than the individual level.

\section{Background}

\section{Protestantism in Brazil}

Protestant missionary activity began in Brazil in the mid-nineteenth century. Missionaries founded schools, hospitals, radio stations, printing presses, and clinics, yet made few converts until the second half of the $20^{\text {th }}$ century (Ferreira 1959; Belloti 2000; Chestnut 1997). The number of Protestants also increased through immigration, particularly German immigration to southern Brazil. Yet, even today these mission/mainline Protestant denominations (Lutheran, Presbyterian, Anglican, and Baptist) ${ }^{1}$ make up only about 4\% of the population (Instituto Brasileiro de Geografia e Estatística 2012).

The majority of Protestants in Brazil are Pentecostal. Pentecostals first came to Brazil in the early $20^{\text {th }}$ century, but spread rapidly in the second half of the $20^{\text {th }}$ century, particularly among the poor and in urban areas. Most Pentecostals are part of Brazilian initiated and controlled denominations and churches and have less connection with foreign missionaries. Leadership in Pentecostal churches typically requires less formal education and leaders are often recruited from the local community. Moreover, their highly participatory services focusing on spiritual gifts are easily accessible and relevant to the felt needs of ordinary people (Vingren 1987; Freston 1995; Chestnut 1997; Mariano 2004). According to the 2000 Brazilian census, $11.7 \%$ of the population now consider themselves Pentecostal.

\footnotetext{
${ }^{1}$ Both the "mainline" and "mission" labels can be misleading. "Mainline" can be misleading because the word comes from the United States and often has the connotation to being theologically liberal, where as many of the "mainline" Protestants in Brazil are theologically conservative. "Mission" can be misleading since a significant portion of these Protestants are immigrants (particularly German Lutherans), and all these denominations are now firmly under indigenous leadership.
} 
Within Pentecostalism there are several distinct families of churches and a bewildering array of denominations. One important distinction is between "traditional" Pentecostals and "neo-Pentecostals" (Cox 1995). ${ }^{2}$ Neo-Pentecostal theology emphasizes that God materially blesses those who have faith and serve him well. One common teaching is that if people want to become rich, they should give "seed money" to their local church. God will see this seed and bless contributors with a far greater financial harvest.

Regardless of these distinctions, most Protestant denominations in Brazil emphasize abstaining from alcohol and drugs (or at most moderate use of alcohol), avoidance of sex outside of marriage, commitment to family, modesty in dress, avoidance of corruption, etc., (e.g., Chestnut 1997). Also, while both Protestant and Catholic clergy decry violence, premarital pregnancy, and abuse of drugs and alcohol, ethnographic evidence suggest that Protestants are more successful than the Catholic Church at recruiting young people and convincing them to make a radical break from dominant cultural patterns with respect to alcohol use and sexual behavior (e.g., Burdick 1993; Hallum 2003; Brenneman 2012). ${ }^{3}$ There are also clear differences between the moral and behavioral codes of Candomblé and related Afro-Brazilian religious traditions that may compete with Protestant churches, particularly in non-White communities (Selka 2010).

\section{The Impact of Protestantism on Earnings}

There are a number of possible mechanisms through which Protestantism may influence male earnings in Brazil.4 Some mechanisms are the result of distinct emphases within Protestantism relative to Catholicism or Afro-Brazilian religious traditions, while others would apply equally to devout Protestants

\footnotetext{
${ }^{2}$ Other distinctions are between Unitarian and Trinitarian Pentecostals, whether speaking in tongues is an essential sign of being baptized by the Holy Spirit or merely a common sign of it, etc.

${ }^{3}$ This evidence is consistent with ethnography and statistical research from other countries in Latin America (e.g., Brusco 1995; Sherman 1997).

${ }^{4}$ In our analysis, we limit the sample to men. Thus, we focus on mechanisms through which Protestantism may influence the earnings potential of men. Some of these mechanisms do not necessarily apply to women.
} 
and Catholics. However, in the Brazilian context Protestants are typically more religiously active than Catholics and thus may accrue more of the benefits and costs of religious practice.

In line with the journalistic account in the introduction, Protestantism may have a positive influence on health, and in particular on the use of alcohol and other drugs. Since the $19^{\text {th }}$ century, conversionary forms of Protestantism have been consistently associated with lower-levels of alcohol consumption and drug use. In many countries, revivalist Protestants helped spur the temperance movement in reaction to a rapid increase in the supply and consumption of distilled alcohol. Historians suggest that temperance was associated with economic uplift in both frontier and urban communities (Johnson 1978; Blocker 1989) and Protestant activists helped spread temperance worldwide (Woodberry 1996).

Contemporary statistical evidence from the US suggests that highly religious people and theologically conservative Protestants are less likely to abuse alcohol and drugs (e.g., Ford and Kadushin 2002; Wallace et al. 2003; Bazargan et al. 2004; Chitwood, Weiss and Leukefeld 2008; Jang, Bader and Johnson 2008) and less likely to smoke (Berg et al. 2009). Ethnographic evidence from Latin American also suggests that Protestantism diminishes alcohol and drug consumption as (Burdick 1993; Brusco 1995; Sherman 1997; Robbins 2004; Smilde 2007) and that these behavioral prescriptions are strongest among religious groups that have thrived among the poor (Freston 1995). In one ethnography about conversion among poor, urban men in Caracas, Venezuela, escaping substance abuse played a role in $44 \%$ of the conversions (Smilde 2007). Available survey data on use of alcohol has also indicated a strong association between Protestantism and diminished consumption of beer, cane liquor (cachaça), and other alcoholic beverages (Almeida and Coutinho 1993; Almeida-Filho et al. 2004; Barros et al. 2007; Cardim et al. 1986; Carlini et al. 2006; Galduroz et al. 2003).

In elite circles abstaining from alcohol may diminish networking opportunities and thus hamper economic prospects, but in poor communities temperance may help people to work more consistently and effectively and to save a higher proportion of their income. Moreover, ethnographic research in Latin America suggests that as a result of refraining from alcohol, gambling, etc., Protestants are able to save 
more money to invest in cash crops, land, housing, and consumer durables (Willems 1967; O'Conner 1979; Turner 1979; Aulie 1979; Annis 1987; Brusco 1995; Martin 1995).

Beyond the effect of Protestantism on use of alcohol, there is substantial evidence that, among Christians, religiosity is associated with greater health and longer life expectancies (e.g., Hummer et al. 1999; 2004; Lehrer 2004; Woodberry 2008; Ellison et al. 2010). Research on religion and health within Brazil is limited, however there is evidence that infant mortality is about 10 percent lower among Protestants than Catholics, holding all else equal (Wood, Williams, and Chijiwa 2007). Additionally, the close face-to-face congregations frequent among Protestant groups in Brazil often serve as a social security net for members - when someone is sick other members often help take care of basic needs (Mariz 1992; also see Brusco 1995; Trinitapoli 2007; Smilde 2007). Health crises can be a major reason for people to fall into debt or lose their jobs, whereas better health may improve people's work efficiency and increases their time horizons, thus increasing earnings - particularly for people engaged in manual labor.

A third route through which Protestantism may influence earnings is through helping in the process of securing and holding a better paying job. In Brazil, for many jobs, the vast majority of hiring is done by word-of-mouth, and social networks and clientelism are an essential means of gaining access to job opportunities (Telles 2004, p. 162; Schepper-Hughes 1992). The same closeness of Protestant congregations that serves as a social security net for members may also be an important source of job referrals, especially for those without access to other social networks (Roberts 1968; Martin 1990: Smilde 2007: 79).

In addition, Latin American ethnographic evidence suggests that employers prefer to hire evangelicals because they perceive them to be better and more honest employees (Mariz 1992; B. Martin 1995: 110-112; Robbins 2004: 136). Reduced alcohol and drug consumption can make people more 
reliable employees and less likely to steal to pay for an addiction. Moreover, internationally there is substantial statistical evidence that active Protestants are more averse to theft and other petty crimes. ${ }^{5}$

Imputed favor by potential employers can increase income, especially for people who live in poor, marginalized communities where attachment to the formal economy is lower and who face greater employment discrimination, such as many poorly educated people of color (Telles 2004, pp. 139-172). Imputed favor may also help small businesspeople and evangelical merchants are considered more honest (Martin 1995: 110-112; Robbins 2004: 136; Smilde 2007: 79). ${ }^{6}$ However, there is some ethnographic evidence that imputed favor towards evangelicals is diminishing (Smilde 2007: 79-80)

Fourth, conversion to Protestantism, particularly Pentecostalism, may help Afro-Brazilians mitigate racism and reduce some of the psychological costs of racism on their identity (Burdick 1999: 2005). In Brazil, darker skinned people tend to be at the bottom of the racial, educational and economic hierarchy and often carry scars of shame and resentment. However, converts learn that they are loved by God, are brothers and sisters in Christ, and have access to "gifts of the Spirit" regardless of their access to material and cultural resources. In fact, blacks are generally viewed as having disproportionate access to spiritual and musical gifts and are often put in public positions. Thus, one black informant said "The first thing I noticed when I entered the Assembly of God was how many people of my color were up there [at the front of the church]" (Burdick 1999: 124). Another black informant said "In [church], you feel respected, you feel free. People really look at you as a brother in Christ" (p. 123). This seems to shape AfroBrazilians' perceptions of themselves and of the broader community. One informant declared "I could no

\footnotetext{
${ }^{5}$ Both Protestantism and religiosity are associated with greater rule following behavior, greater aversion to corruption, and less willingness use resources from work for personal benefit (Triesmann 2000; Stark 2001; Guiso, Sapienza and Zingales 2003; Stack and Kposowa 2006; Woodberry 2008). This pattern is especially true for evangelicals (Grasmick, Bursick, and Cochran 1991; Sikkink and Smith 1998; Perrin 2000). In addition, highly religious people are moderately less likely to engage in crime and the influence of religiosity on crime is stronger in neighborhoods where crime is widespread (Johnson et al. 2000a; 2000b; 2001; Baier and Wright 2001). Still, Protestants have their share of corruption, including some high profile corruption scandals by neo-Pentecostal leaders in Brazil (Freston 2001; Woodberry and Shah 2004).

${ }^{6}$ For example, one of Smilde's respondents reports "Yes, all my clients [know I am Evangelical]. When I first talk with them, I tell them that I am a professing believer in the Gospel of Jesus Christ and they trust me a lot. Some clients have paid me a thousand dollars or more without signing them a receipt. They have trusted me because I come recommended and they have the impression that Evangelicals are responsible." (2007: 79).
} 
longer pretend that discrimination doesn't happen outside the church. As long as you are in the church, you are treated differently. I hadn't seen how bad things were with prejudices until I entered a church: the contrast really is amazing" (p. 124).

These new experiences and beliefs seem to shape Afro-Brazilians' views of themselves, expectations of others, and ability to hold whites to account for their racism. One black church member said "I had always known that prejudice existed. But it was only after knowing the Gospel that I saw how evil it was, how it was against the will of God. And in church, when I saw my own brethren in the Spirit acting this way, I thought, 'How can a people fearful of God act this way, have such thoughts?'” (p. 124).

Since the early 1980s Afro-Brazilian Protestants have been organizing themselves to fight prejudice: speaking against it in church and distributing literature using Biblical arguments against racism and highlighting the role of Africans in the Bible (Burdick 1999; 2005). Moreover, Protestant leaders realize that if they want Protestantism to continue to spread among Afro-Brazilians, they need to take Afro-Brazilian concerns seriously. Some concrete indicators of the impact of Protestants on Brazilian racial attitudes is (1) a greater willingness of darker skinned Protestants to identify themselves as black (e.g., negro, preta) and (2) a higher rate of inter-racial marriage among Protestants - particularly of black women with white men (Burdick 1999). To the extent that Protestants also break down racial discrimination in employment among their fellow congregants, this may benefit the financial conditions of non-whites in their area. If this mechanism is important we would expect the spread of Protestantism to have a greater influence on the economic conditions of poor non-whites.

Fifth, ethnographic evidence suggests that in marginalized communities in Latin America conversion to Protestantism often leads men to become more committed to their wives and children (Burdick 1993; Brusco 1995; Sexton and Woods 1977; Sherman 1997; Hallum 2003; Robbins 2004; Smilde 2007). In Smilde's ethnographic sample of urban underclass men, solving marital problems was important in the conversion of $20 \%$ of his sample $(2007: 56,93)$. Both conversion and attachment to family increased the desire for self-improvement among many of the men in his sample. As one of his 
respondents said "I began to be concerned about reading, about advancing in my studies, advancing in some personal areas" (2007: 81). Commitment of fathers to spouses and children may benefit the educational and economic prospects for children (McLanahan and Sandefur 1994; Booth and Crouter 2002; Wolfinger 2005; Wolfinger and Wilcox 2008).

Sixth, conversion to Protestantism helps urban, underclass men escape violence. In Smilde's ethnographic sample, 33\% reported that escaping violence was important to their conversion (2007: 56, 62-76). . Poor urban areas in Brazil often have extremely high levels of violence (Caldeira 2001). Once one person is attacked it often leads to chains of violence as victims and their friends seek revenge and as perpetrators and their friends try to preemptively kill those who are likely to kill them. Conversion to Protestantism is considered a legitimate way to leave gangs and allows men to step out of the cycle of vendettas without losing honor. Moreover, because evangelicals are considered less likely to take violent revenge, they are less likely to be killed in preemptive attacks (Smilde 2007: 56, 62-76; Brenneman 2012). In addition, almost everyone in the popular classes believes in the Christian God and the Bible, even if they do not practice. Thus, they often fear attacking people who are closely connected with religion. Smilde's respondents reported that carrying a Bible prominently and vocally proclaiming their faith helps protect them against attack (2007: 70-72, also see Brenneman 2012). Avoiding theft, injury, or imprisonment can help the economic potential of those in marginalized communities.

There are, of course, other mechanisms through which religiosity in general or Protestantism in particular, may improve economic conditions and earnings in communities in Brazil. Some of these mechanisms would presumably increase the income of Protestants or religious individuals: e.g., more education, greater literacy among those with low levels of education, or even increased disposition toward engaging in entrepreneurial activity. Other mechanisms would presumably increase the income/wealth of the community more broadly: e.g., lower crime, lower corruption, more volunteerism, and greater

\footnotetext{
${ }^{7}$ One of Smilde's informants said bluntly: "The problem [of vendetta violence] got so serious that I converted to the Gospel." (2007: 66).
} 
provision of resources by competing religious groups. Finally, some aspects of Protestantism may reduce people's incomes. Many Protestant groups emphasize tithing (giving 10\% of your income to the church) and expect active participation - often at multiple services per week. The time and money invested in church may reduce the time and money available for work and other investments.

\section{Data and Methods}

One of the longest series of data on age, education, religion, and income available to researchers comes from the Brazilian censuses taken in 1960, 1970, 1980, 1991, and 2000. Microdata from these censuses are available from long-form questionnaires administered to every fourth household (25\% samples) in 1960, 1970 and 1980, and to every fifth (20\%) or every tenth (10\%) household in 1991 and 2000 depending on the size of the municipality. In all cases, there are records for every individual in the selected households that contain information on that person's age, sex, marital status, educational attainment, enrollment in school, religious affiliation and, if employed, occupation and earnings. Since the income data for 1960 are only coded categorically, we restrict the present analysis to 1970-2000. The coding of religion is progressively more detailed in each successive census, enabling one to look at a wide variety of Protestant churches in the later censuses. However, to permit a classification that is consistent across the four censuses used in this analysis, the variable we construct here is simply the proportion Protestant.

Since we are not able to follow individuals through time, from census to census, there is no possibility of assessing the earnings of individuals before and after conversion to Protestantism with these data. However, we can follow groups of individuals through time, and observe similarly defined groups across regions in space, and see how the earnings of the group changes as the proportion of Protestants in the group varies over time and space, which is likely the "next best" way to address the issue of selectivity. The groups we have chosen to follow/observe in this study are defined on the basis of the two 
available indicators of human capital, education and age, with the latter being interpreted as a proxy for experience in the labor force, as well as spatial location and census year.

The lowest level geographic identifier on these records is the municipio. In previous work, Potter, Schmertmann and Cavenaghi (2002) established minimum comparable areas that account for the changing definitions and division of municipalities through the years, as the absolute number of municipalities has increased from approximately 2,300 in 1960 to 5,280 in 2000. Working with these census data, they found it convenient to aggregate municipalities to microregions, yielding 502 comparable areas across the five censuses. Thus, it is possible to calculate area means of monthly earnings and the proportion Protestant for groups defined by age and education in each of these 502 areas at each of the five points in time.

We categorized age as follows: 15-24, 25-34, 35-49, and 50-64. Our educational attainment classification takes into account the specifics of the Brazilian population. The first group, zero to four years of schooling, includes illiterate people and those in the first phase of elementary school. The second group, five to eight years of schooling, contains people in the second phase of elementary school. The third and final group is comprised of people in high school (nine to eleven years of schooling), and people with some college education (at least twelve years of schooling).

For each microregion, age-education, and year cell, the mean monthly earnings of those in the paid labor force was calculated. Since there were changes in Brazilian currency across time, as well as dramatic inflation during the period, the nominal wage was converted to base one in January 2002. To correct for currency changes, wages in 1970 and 1980 were divided by 2,750,000,000,000; and in 1991, they were divided by $2,750,000$. To correct for inflation, wages were divided by 0.000000000000264 in $1970 ; 0.000000000005778$ in $1980 ; 0.000067602304350$ in 1991 ; and 0.902716061809642 in 2000 , as suggested by Corseuil and Foguel (2002). We also calculated the proportion Protestant among employed males in each cell. In this study, we restrict the analysis to males in order to avoid the complications resulting from rapidly changing rates of female labor force participation. Moreover, many of the mechanisms through which Protestantism may influence economic development in Brazil seem to apply 
primarily to men. Finally, we analyze earnings rather than employment since labor force participation rates vary only slightly by age and education among males.

\section{Regression framework}

Considering that there were four censuses, 12 age-education groups, and 502 consistent microregions, we had potentially 24,096 observations. The models we selected to explain variation in mean earnings across these observations included a large number of terms to account for the differences that might arise from the group (that is the combination of age group and education group), the year, the macroregion, the microregion, the interaction between year and group, the interaction between macroregion and group, the joint interaction between year, macroregion and group, as well as that between year and microregion. Apart from these fixed-effects, the only other predictor in the first model was the proportion Protestant among the individuals in the cell defined by age, education, microregion, and census year. We ran the regression without using weights, and excluded cells with fewer than 25 people receiving income. ${ }^{8}$

Following the Borjas' notation (2003), we estimated the model:

$$
\begin{aligned}
& \log \left(\mathrm{Y}_{\mathrm{ijrt}}\right)=\varphi_{i j} P_{i j r t}+s_{i}+x_{j}+\pi_{t}+\delta_{m}+\gamma_{r}+\left(s_{i} \times x_{j}\right)+\left(s_{i} \times \pi_{t}\right)+\left(x_{j} \times \pi_{t}\right)+\left(s_{i} \times x_{j} \times \pi_{t}\right) \\
& +\left(s_{i} \times \delta_{m}\right)+\left(x_{j} \times \delta_{m}\right)+\left(s_{i} \times x_{j} \times \delta_{m}\right)+\left(s_{i} \times x_{j} \times \pi_{t} \times \delta_{m}\right)+\left(\gamma_{r} \times \pi_{t}\right)+\varepsilon_{i j r t}
\end{aligned}
$$

where $\log \left(\mathrm{Y}_{\mathrm{ijt}}\right)$ is the logarithm of the mean value of monthly earnings for those who have education $i$ $(\mathrm{i}=1,2,3)$, experience $j(j=1, \ldots, 4)$, and are observed in microregion $r(r=1, \ldots, 502)$ which is part of macroregion $m$ at time $t(t=1970,1980,1991,2000) ; P_{i j r t}$ is the proportion Protestant in the cell; $s_{i}$ is a vector of fixed effects indicating the group's educational attainment; $x_{j}$ is a vector of fixed effects indicating the group's work experience; $\gamma_{r}$ is a vector of fixed effects indicating the microregion; $\delta_{m}$ is a vector of fixed effects indicating the macroregion; and $\pi_{t}$ is a vector of fixed effects indicating the time

\footnotetext{
${ }^{8}$ Because of the 25 case exclusion in the religion models, Table 3 (1970-2000) dropped from 23,839 to 19,727 observations, and Table 4 (1980-2000) dropped from 17,992 to 15,669 observations.
} 
period. The linear fixed effects in equation (1) control for differences in earnings across schooling groups, experience groups, microregions, and over time. The first four interactions control for the possibility that the impact of education and experience changed over time, that the experience profile of earnings differs by education group, and that this interaction may vary over time. The second four interactions control for the possibility that the impact of education and experience differed across macroregions, and that the interaction between education and experience may vary across macroregions. The next to last interaction term allows for any change in the interaction between education and experience over time to vary by macroregion as well. The last interaction, $\left(\gamma_{r} \times \pi_{t}\right)$, allows for the local microregion fixed effects to vary over time. Finally, the estimated impact of the proportion Protestant on earnings, $\phi_{i j}$, is held constant over time and across macroregions.

The logic of this model hinges on identifying any influence that religion might have on changes in earnings in a group through time, or in altering the overall pattern of earnings differentials across groups in a census year in a particular microregion. Such a cross-section effect could be estimated either if there was a difference in the proportion Protestant across the twelve groups in a microregion, or if the proportion Protestant had a different influence on income in different age-education groups. In a second model, we introduce race as a second predictor variable, calculating the proportion non-White in each cell, and estimating its main effect as well as the interaction with the proportion Protestant in the cell.

No method can completely eliminate the possibility of selection bias. However, the method we have chosen relies on an enormous number of fixed effects that are intended to account for the possible influence of unobserved confounding variables on both the education and experience profile of earnings, as well as the overall level of earnings in the local microregion. There are two other ways in which our strategy is conservative. First, we analyze only those who are in the labor force - not those who are unemployed. Ethnographic evidence from Latin America suggest that marginalized people who become Protestant are more likely to move into the formal economy (Smilde 2007, also see Freeman 1986). Thus, dropping the unemployed may underestimate the association between Protestantism and growth in income. Second, we 
analyze growth in income only within the same education categories. To the extent that Protestantism promotes formal education ((Tax and Hinshaw 1970; Early 1973; Sexton 1978; Annis 1987; Brusco 1995; Sherman 1997)', and formal education increases income, our analysis will underestimate the impact of Protestantism on income.

\section{Results}

Table 1 shows the percent Protestant among the male population 15-64 years of age in each of the census years. These proportions are somewhat lower than for the whole population since the proportion Protestant is higher among women than men. Nevertheless, the proportion Protestant more than doubles over this 30 year period, reaching nearly 11 percent in 2000. An interesting change takes place in the spatial location of Protestants over the period (See Figure 1). In 1970, the highest proportions Protestant are found in the Southern parts of Brazil where there was considerable immigration from Germany. Later on, as Traditional Protestant Churches are eclipsed by Pentecostal Churches, the highest proportions are found in large cities along the coast such as Rio de Janeiro and Sao Paulo, and in the North and CentralWest regions of Brazil.

\section{$>>$ Table $1<<<$ \\ $>>$ Figure $1<<<$}

Over this period in Brazil, there are also considerable shifts in the age distribution, and in educational attainment. Table 2 shows the proportion of the male population found in each of the twelve age-education groups in each of the four census years for all of Brazil. The proportion with 0-4 years of schooling falls dramatically, especially among those under age 50, while the proportion with nine or more years of education increases, mainly in those same age groups. The proportion Protestant in each of the age-education groups in each census year is shown in Figure 2. There does not seem to be much variation

\footnotetext{
${ }^{9}$ Statistical evidence from the developing world confirms that Protestants are disproportionately educated and have higher educational expectations for their children (Garner 2000; Woodberry 2004; Blunch 2008; Heaton, James, and Oheneba-Saky 2009; Roemer 2010; Nunn 2010; Zhai and Woodberry 2011).
} 
by either age or education in the proportion Protestant, and this proportion seems to increase quite uniformly through time in all twelve of the groups.

>> Table $2<<<$

$>>$ Figure $2<<<$

To provide an intuitive demonstration of the logic that underlies our regression model, we developed a simple exercise. Since we are not looking at individuals, but rather group means, what we are interested in is how the pattern of group means changes as the proportion Protestant varies. The top panel of Figure 3 shows the level of mean male earnings in each of the 12 age-education groups for the whole of Brazil in the year 2000. As would be expected, incomes increase with education, and also with age. The difference in earnings according to education is greater in the older as compared to the younger age groups. The next step in the exercise is to construct that same figure, but instead of basing it on the entire population in 2000 , we use only the 10 percent of microregions that had the lowest proportions Protestant. Also, in this case, for the vertical axis, we use the level of income relative to that of the group with 5-8 years of education in the same age group. Finally, in the third panel, we construct the same figure for the 10 percent of microregions with highest percent Protestant in 2000.

\section{$>>$ Figure $3<<<$}

If the proportion Protestant were related to income in a similar way in each of the 12 age-education groups, we would not expect to see much of a shift between the second and third panels. However, if the proportion Protestant were to make a large difference in some groups but not in others, then we would observe a different pattern in the two panels. This is indeed what we see in Figure 3. Relative to those with 5-8 years of education, mean income is considerably lower among those with $0-4$ years of education in all four of the age groups in the middle panel, with the greatest differences found in the oldest age groups. In the bottom panel for the microregions with the most Protestants, these differentials are considerably attenuated. On the other hand, the premium earned by those with 9 or more years of education is fairly similar. The differentials between 5-8 years of education and those with more education are about the same in the microregions with the least Protestants as they are in the microregions 
with the most Protestants. Such a contrasting pattern is consistent with the proportion Protestant positively impacting the earnings of those with the least education, but having little or no effect on those with five or more years of education.

The first regression model parallels the preceding exercise, but includes all census years and all 502 microregions. The coefficients of interest refer to the relation between the proportion Protestant in each age-education group and the mean wage for that group, adjusted for the time and macroregion varying influence of the group on income, and the time varying influence of the microregion on income. These coefficients are shown in Table 3. There are very large and highly significant coefficients for all four of the groups with 0-4 years of education, but much smaller coefficients for the other eight groups with higher levels of education.

\section{>> Table $3<<<$}

Since there is known to be considerable discrimination by race in the Brazilian labor market (Telles 2004), we wanted to explore the possibility that Protestantism might serve as a marker to offset the negative influence of black or brown skin color and Afro-Brazilian descent. Figure 4 shows the proportion of the male population of labor force age that is reported as non-White in each microregion in each of the three education groups in the 2000 census. There is a strong geographical gradient with the largest proportions non-White being found in the North and Northeast of Brazil, but also variation with education so that there are higher proportions non-White among those with 0-4 years of education. Information on race was not available in the 1970 census, but was available in 1980, 1991, as well as 2000.

\footnotetext{
$>>$ Figure $4<<<$
} 


\section{Including Race}

We augmented our previous model to include this information as follows:

$$
\begin{aligned}
& \log \left(\mathrm{Y}_{\mathrm{ijrt}}\right)=\varphi_{i j} P_{i j r t}+\lambda_{i j} N W_{i j r t}+\phi_{i j}\left(P_{i j r t} \times N W_{i j r t}\right)+s_{i}+x_{j}+\pi_{t}+\gamma_{r} \\
& +\left(s_{i} \times x_{j}\right)+\left(s_{i} \times \pi_{t}\right)+\left(x_{j} \times \pi_{t}\right)+\left(s_{i} \times x_{j} \times \pi_{t}\right)+\left(s_{i} \times \delta_{m}\right) \\
& +\left(x_{j} \times \delta_{m}\right)+\left(s_{i} \times x_{j} \times \delta_{m}\right)+\left(s_{i} \times x_{j} \times \pi_{t} \times \delta_{m}\right)+\left(\gamma_{r} \times \pi_{t}\right)+\varepsilon_{i j r t}
\end{aligned}
$$

where $N W_{i j t}$ is the proportion non-White in each cell, $\lambda_{i j}$ are the estimated time invariant effects of the proportion non-White, and $\varphi_{i j}$ are the estimated time invariant effects of the interaction between the proportions Protestant and the proportions non-White. The model uses only data from 1980 onwards. The estimated effects for the four age groups with 0-4 years of education are shown in Table 4 . The effects of the proportion non-White are negative, large in size, and increase with age. However, in this model the main effect of the proportion Protestant on earnings becomes insignificant and negative, with all of the positive impact of Protestantism having shifted to the interaction between the proportion Protestant and the proportion non-White. The estimated coefficients of the interaction terms are positive, large, and increase with age. However, the interaction coefficient for the 15-24 age group is not statistically significant.

\section{>> Table $4<<<$}

To illustrate these estimated effects, we have plotted how the earnings of males with $0-4$ years of education in each of the four age groups would be expected to vary across communities that varied with respect both the proportion Protestant and the proportion non-White (Figure 5). Estimates are shown for microregions that have zero, ten, twenty and thirty percent Protestant; combined with zero, thirty, sixty, and ninety percent non-White. Income is shown relative to what it would be in a community with no Protestants and no non-Whites. Looking at the plot for the first age-group, 15-24, we see that if the microregion has no non-Whites, there is no discernible variation in estimated earnings of young men with low education with an increase in the proportion Protestant in the community. However, if the proportion of non-Whites is sixty percent, increasing the proportion Protestant from zero to thirty percent yields an 
Increase in estimated earnings from a relative value of about 0.62 to 0.72 . In other words, while an increase in the proportion Protestant does not entirely offset the lower earnings of communities with sizeable proportions of non-Whites, it appears to mitigate this problem, possibly by alleviating the amount of discrimination.

Looking across the four age-groups the pattern is similar, but the effect of Protestantism in alleviating the penalty associated with a higher proportion of non-Whites is greater, the older the agegroup. In all age-groups, the higher the proportion of non-Whites, the larger is the positive influence of a higher proportion Protestant. Moreover, in no age-group is the proportion Protestant associated with an increase in earnings in entirely White communities.

\section{$>>$ Figure $5<<<$}

\section{Discussion}

We observed a strong and significant association between the proportion Protestant and male earnings across groups in Brazil defined on the basis of place, age and education, but the association was strongest among those groups with the lowest level of education: those who had completed less than five years of schooling. When we introduced race into our model, the relationship between Protestantism and earnings among males with low educational attainment was found to be greatest among groups with high proportions of non-whites. That is to say we found a strong relationship between earnings and Protestantism, but one that seems to be concentrated among less educated people of color. We began this investigation with the idea that Protestantism might increase the earnings of some of the least fortunate members of Brazilian society. Our statistical results suggest this is the case. Our methods do not allow us to determine which mechanisms fostered this increase in income (assuming the association is causal). ${ }^{10}$ However, the strong interaction that we found with race helps increase or decrease the plausibility of

\footnotetext{
${ }^{10}$ Our methods also do not allow us to measure any influence religion may have on either education or employment rates.
} 
different explanations. The mechanism that operates among the least educated segment of the population should be something that disproportionately impacts non-whites with low-levels of education.

There is little or no evidence that non-Whites consume more alcohol or have a greater incidence of problem drinking than do Whites in Brazil (Almeida-Filho 2005). ${ }^{11}$ However, there is ample evidence of substantial discrimination in earnings against poorly educated people of color in the census data (see the coefficients of the proportion non-White in Table 4) as well as in the literature (Telles 2004, pp. 139172). Certainly, one mechanism that is consistent with our results is that the reputation Protestants have for being honest workers may diminish the discrimination that non-Whites with little education experience in the Brazilian job market. Imputed favor is likely to be most important for those without educational credentials, as might be the advantage of a social network acquired through membership in a church in learning about jobs, or being recommended for them. Another possibility is that the relation between religion and vulnerability to crime operates mainly in communities with a high proportion of non-Whites. This might be the case if black-white segregation leads to higher rates of non-White victimization, as in the U.S. (Peterson and Krivo 1993). Finally, emerging Afro-Brazilian movements within Protestantism may diminish white racism in congregations and denominations with substantial Afro-Brazilian constituencies. This, in turn, may have expanded the employment opportunities for AfroBrazilians.

Our study of Brazil is comprehensive in that it incorporates information from a thirty-year period, and 502 consistent subdivisions of the entire country. However, the census data we use suffer from a number of limitations. First, in order to have a consistent classification across all four censuses, we do not subdivide Protestants into the expanding number of individual denominations that compose this very broad religious categorization. Second, the census data do not provide detail on religious practices and attendance at services, or on possible mediating behaviors such as abstaining from alcohol. Finally, we are not able to follow individuals from census to census, and thus assess the impact of conversion on

\footnotetext{
${ }^{11}$ Still, excessive alcohol consumption may have a stronger negative effect on people who are marginalized in other ways and who thus have fewer resources to counteract the costs of excessive consumption.
} 
behavior and earnings at the individual level. Thus we necessarily leave open the question of whether it is conversion from Catholicism, from an Afro-Brazilian religion, or from no religious involvement that is driving the relationship we observe between Protestantism and earnings.

These limitations mainly affect our ability to know exactly how Protestantism is connected to higher earnings for non-Whites with low levels of education, rather than the likelihood of a causal relationship between religion and earnings. Of course, the method we have chosen does not completely rule out the possibility of finding a spurious association between earnings and religion, but the extremely large number of fixed-effects that we have estimated makes it quite difficult to construct an explanation of our findings that would somehow transfer the responsibility for the association onto other unmeasured variables. There would need to be some factor that could somehow explain the growth of Protestant churches in the places where non-Whites with low educational attainment had, for other reasons, the greatest chance of receiving greater earnings relative to others in the same locality.

In closing, we would like to note that the relationships we have uncovered contribute to the growing literature on racial inequality and discrimination in Brazil, which to date has given little space to the role of religion in moderating the pernicious effect of race on economic outcomes in Brazil (Telles 2004). Our results also contrast with much of the research that has been carried out on the influence of religion on earnings in the United States, most of which has found only relatively moderate effects (eg. Tomes 1984). Of course, these results are specific to a single country during a period of rapid change in religious composition. Whether the effects we have observed will be found in other settings where there is a sizeable proportion of the labor force with little or no education and discrimination according to race or ethnicity is an interesting question for future research. Another open question is whether such effects will diminish over time in Brazil as Protestant churches grow, educational attainment increases, and the Catholic Church responds to religious competition. 


\section{References}

Almeida, Liz M., and Evandro S. F. Coutinho. 1993. "Prevalência de consumo de bebidas alcoólicas e de alcoolismo em uma região metropolitana do Brasil.” Revista de Saúde Pública, 27, 1: 23-29.

Almeida-Filho, Naomar, Ines Lessa, Lucélia Magalhães, Maria J. Araújo, Estela Aquino, Ichiro Kawachi, and Sherman A. James. 2004. "Alcohol drinking patterns by gender, ethnicity, and social class in Bahia, Brazil.” Revista de Saúde Pública, 38, 1: 45-54.

Almeida-Filho, Naomar, Ines Lessa, Lucélia Magalhães, Maria J. Araújo, Estela Aquino, Ichiro Kawachi, and Sherman A. James. 2005. "Social inequality and alcohol consumption-abuse in Bahia, Brazil: Interactions of gender, ethnicity and social class," Social Psychiatry and Psychiatric Epidemiology 40: 214-222

Annis, Sheldon. 1987. God and Production in a Guatemalan Town. Austin: Austin University Press.

Aulie, Henry Wilbur. 1979. The Christian Movement among the Chols of Mexico with Special Reference to the Problems of Second Generational Christianity. Ph.D. dissertation, Fuller Theological Seminary.

Baier, Colin J., and Bradley RE Wright. 2001. "“If you love me, keep my commandments": A metaanalysis of the effect of religion on crime." Journal of Research in Crime and Delinquency 38(1): 321.

Barros, Marilisa B., Neury J. Botega, Paulo Dalgalarrondo, Letícia Marín-León, and Helenice B. Oliveira. 2007. "Prevalence of alcohol abuse and associated factors in a population-based study." Revista de Saúde Pública, 41, 4: 502-509.

Bazargan, Shahrzad, Darren E. Sherkat, and Mohsen Bazargan. 2004. "Religion and Alcohol Use among African-American and Hispanic Inner-City Emergency Care Patients." Journal for the Scientific Study of Religion. 43: 419-428.

Belloti, Karina. 2000. Uma igreja invisible? Protestantes históricos e meios de comunicação de massa no Brasil. Thesis. Universidade Estadual de Campinas, Campinas, São Paulo, Brasil.

Berg, Carla, Won S. Choi, Harsohena Kaur, Nicole Nollen, and Jasjit S. Ahluwalia. 2009. "The Roles of Parenting, Church Attendance, and Depression in Adolescent Smoking." Journal of Community Health. 3491): 56-63.

Blocker, Jack S. 1989. American Temperance Movements: Cycles of Reform. Boston: Twayne Publishers.

Blunch, Niels-Hugo. 2008. "Religion and Human Capital in Ghana." Paper presented at the annual meeting of the Population Association of America, New Orleans, LA, April 18.

Booth, Alan and Ann C. Crouter. 2002. Just Living Together. Mahwah, NJ: Lawrence Erlbaum Associates

Borjas, George J. 2003. "The labor demand curve is downward sloping: Reexamining the impact of immigration on the labor market," Quarterly Journal of Economics 18(4): 1335-1374.

Brenneman, Robert E. 2012. Homies and Hermanos: Gods and Gangs in Central America. New York: Oxford University Press.

Brusco, Elizabeth E. 1995. The Reformation of Machismo: Evangelical Conversion and Gender in Guatemala. Austin, TX: University of Texas Press.

Burdick, John. 1993. Looking for God in Brazil: The Progressive Catholic Church in Urban Brazil's Religions Arena. Berkeley: University of California Press. 
Burdick, John 1999. "What is the Color of the Holy Spirit? Pentecostalism and Black Identity in Brazil." Latin American Research Review 34(2): 109-131.

Burdick, John. 2005. "Why is the Black Evangelical Movement Growing in Brazil?" Journal of Latin American Studies 37(2): 311-332.

Caldeira, Teresa P. R. 2001. City of Walls: Crime, Segregation, and Citizenship in Sao Paulo. Berkeley: University of California Press.

Cardim, Marisa S., Simone G. Assis, Marcy Sberze, Takumi Iguchi, and Anastácio F. Morgado. 1986. "Epidemiologia descritiva do alcoolismo em grupos populacionais do Brasil." Cadernos de Saúde Pública, 2, 2: 191-211.

Carlini, Elisaldo A. 2006. "Epidemiology of alcohol use in Brazil." Arquivos Médicos do ABC, supplement 2: 4-7.

Chesnut, Andrew. 1997. Born Again in Brazil: The Pentecostal Boom and the Pathogens of Poverty. New Brunswick, NJ: Rutgers University Press.

Chitwood, Dale D. Michael L. Weiss, and Carl G. Leukefeld. 2008. "A Systematic Review of Recent Literature on Religiosity and Substance Use.” Journal of Drug Issues. 653-688.

Corseuil, C., and M. Foguel. 2002. "Uma Sugestão de Deflatores para Rendas Obtidas a Partir de Algumas Pesquisas Domiciliares do IBGE." Texto para Discussão, 897. Rio de Janeiro, RJ, Brazil: Instituto de Pesquisa Econômica Aplicada (IPEA).

Cox, Harvey. 1995. Fire from Heaven: The Rise of Pentecostal Spirituality and the Reshaping of Religion in the Twenty-First Century. Reading, MA: Addison-Wesley Press.

Early, John D. 1973. "Education via Radio among Guatemalan Highland Maya.” Human Organization 32: 221-29.

Ellison, Christopher G., Robert A. Hummer, Amy M. Burdette, Maureen R. Benjamins. 2010. "Race, Religious Involvement, and Health." In Religion, Families and Health: Population-Based Research in the United States. New Brunswick, NJ: Rutgers University Press.

Ferreira, J.A. 1959. História da Igreja Presbiteriana do Brasil. São Paulo, Brasil: Casa Editorial Presbiteriana.

Ford, Julie and Charles Kadushin. 2002. "Between Sacral Belief and Moral Community: A Multidimensional Approach to the Relationship between Religion and Alcohol among Whites and Blacks." Sociological Forum. 17: 255-279.Freeman, Richard B. 1986. "Who Escapes? The Relation of Churchgoing and Other Background Factors to the Socioeconomic Performance of Black Male Youths from Inner-City Tracts." Pp. 353-376 in The Black Youth employment Crisis, edited by Richard B. Freeman and Harry J. Holzer. Chicago: University of Chicago Press.

Freeman, Richard B. 1986. "Who Escapes? The Relation of Churchgoing and Other Background Factors to the Socioeconomic Performance of Black Male Youths from Inner-City Tracts." Pp. 353-376 in The Black Youth employment Crisis, edited by Richard B. Freeman and Harry J. Holzer. Chicago: University of Chicago Press.

Freston, Paul. 1995. "Pentecostalism in Brazil: A Brief History." Religion 25: 119-133. 2001. Evangelicals and Politics in Asia, Africa, and Latin America. New York: Cambridge University Press.

Galduróz, José C. F., Ana R. Noto, Solange A. Nappo, and Elisaldo L. A. Carlini. 2003. "First household survey on drug abuse in São Paulo, Brazil, 1999: principal findings." São Paulo Medical Journal, 121, 6: $231-237$. 
Garner, Robert C. 2000. "Religion as a Source of Social Change in the New South Africa." Journal of Religion in Africa 30(3): 310-43.

Grasmick, Harold G., Robert J. Bursik and John K. Cochran. 1991. "'Render unto Caesar What is Caesar's': Religiosity and Taxpayers' Inclinations to Cheat." Sociological Quarterly. 32: 251-66.

Guiso, Luigi, Paola Sapienza and Luigi Zingales. 2003. "People's Opium? Religion and Economic Attitudes.” Journal of Monetary Economics 50: 225-82.

Hallum, Anne Motley. 2003. "Taking Stock and Building Bridges: Feminism, Women's Movements, and Pentecostalism in Latin America." Latin American Research Review. 38(1): 169-186.

Heaton, Tim, Spencer James, and Yaw Oheneba-Sakyi. 2009. "Religion and Socioeconomic Attainment in Ghana." Review of Religious Research 51(1): 71-86.

Hummer, Robert A., Richard G. Rogers, Charles B. Nam, and Christopher G. Ellison.1999. "Religious Involvement and US Adult Mortality." Demography 36(2): 273-85.

Hummer, Robert A. Christopher G. Ellison, Richard G. Rogers, and Benjamin E. Moulton. 2004. "Religious Involvement and Adult Mortality in the United States: Review and Perspective." Southern Medical Journal. 97(12): 1223-1230.

Instituto Brasileiro de Geografia e Estatística. 2012. Censo Demográfico 2010: Caracteristicas Gerais da Populacao, Religiao e Pessoas com Deficiencia. Rio de Janeiro: IBGE.

Jang, Sung Joon, Christopher D. Bader, and Byran R. Johnson. 2008. "The Cumulative Advantage of Religiosity in Preventing Drug Use.” Journal of Drug Issues. 38(3):771-798.

Johnson, B. R., Spencer de Li, David B. Larson, Michael McCullough. 2000. "A Systematic Review of the Religiosity and Delinquency Literature: A Research Note." Journal of Contemporary Criminal Justice 16(1): 32-52.

Johnson, Byron R., David B. Larson, Spencer De Li, and Sung Joon Jang. 2000. "Escaping from the crime of inner cities: Church attendance and religious salience among disadvantaged youth." Justice Quarterly 17(2): 377-391.

Johnson, B. R., Sung Joon Jang, David B. Larson, Spencer de Li. 2001. "Does Adolescent Religious Commitment Matter? A Reexamination of the Effects of Religiosity on Delinquency." Journal of Research in Crime and Delinquency 38(1): 22-44.

Johnson, Paul E. 1978. A Shopkeeper's Millenium: Society and Revivals in Rochester, New York $1815-$ 1837. Hill and Wang, New York.

Lehrer, Evelyn L. 2004. "Religion as a Determinant of Economic and Demographic Behavior." Population and Development Review 30(4): 707+.

Mariano, Ricardo. 2004. "Expansão pentecostal no Brasil: o caso da Igreja Universal." Estudos Avançados, 18, 52: 121-138.

Mariz, Cecília L. 1992. "Religion and Poverty in Brazil: A Comparison of Catholic and Pentecostal Communities." Sociological Analysis 53: S63-S70.

Martin, Bernice. 1995. "New Mutations of the Protestant Ethic among Latin American Pentecostals." Religion 25: 101-117.

Martin, David. 1990. Tongues of fire: the explosion of protestantism in Latin America. Oxford: Blackwell.

McLanahan, Sara, and Gary Sandefur. 1994. Growing Up with a Single Parent. Cambridge, MA: Harvard University Press. 
Nunn, Nathan. 2010. Christians in Colonial Africa. Unpublished paper. http://www.economics.harvard.edu/faculty/nunn/files/Missions_v2.pdf

O’Conner, Mary. 1979. "Two Kinds of Religious Movement Among the Mayo Indians of Sonora, Mexico." Journal for the Scientific Study of Religion. 18(3): 260-68.

Perrin, Robin D. 2000. "Religiosity and Honesty: Contiuing the Search for the consequential Dimension." Review of Religious Research 41(4): 534-44.

Peterson, Ruth D. and Lauren J. Krivo. 1993. "Racial Segregation and Black Urban Homicide." Social Forces 71(4): 1001-1026.

Potter, J.E., C.P. Schmertmann, and S.M. Cavenaghi. 2002. "Fertility and development: Evidence from Brazil”. Demography. 39(4):739-761.

Robbins, Joel. 2004. "The Globalization of Pentecostal and Charismatic Christianity." Annual Review of Anthropology 33: 117-43.

Roberts, Bryan R. 1968. "Protestant Groups and Coping with Urban Life in Guatemala City." American Journal of Sociology 73: 753-67.

Roemer, Michael K. 2010. "Religion and psychological distress in Japan." Social Forces 89(2): 559-583.

Schepper-Hughes, Nancy. 1992. Death without Weeping: The Violence of Everyday Life in Brazil. Berkeley: University of California Press.

Selka, Stephen. 2010. "Morality in the Religious Marketplace: Evangelical Christianity, Candomblé, and the Struggle for Moral Distinction in Brazil," American Ethnologist 37(2): 291-307.

Sexton, James D. 1978. "Protestantism and Modernization in Two Guatemalan Towns." American Ethnologist 5: 280-301.

Sexton, James D. and Clyde M. Woods. 1977. "Development and Modernization among Highland Maya: A Comparative Analysis of Ten Guatemalan Towns." Human Organization 36(2): 156-172.

Sherman, Amy L. 1997. The Soul of Development: Biblical Christianity and Economic Transformation in Guatemala. New York: Oxford University Press.

Sikkink, David and Christian Smith. 1998. "Religion and Ethical Decision-Making and Conduct on the Job: Reconsidering the Influence of Religion in the Economic and Business Sphere." Presented at the annual meeting of the Society for the Scientific Study of Religion.

Smilde, David. 2007. Reason to Believe: cultural Agency in Latin American Evangelicalism. Berkeley, University of California Press.

Stack, Steven, and Augustine Kposowa. 2006. "The Effect of Religiosity on Tax Fraud Acceptability: A Cross-National Analysis.” Journal for the Scientific Study of Religion. 45(3): 325-51.

Stark, Rodney. 2001. "Gods, Rituals, and the Moral Order." Journal for the Scientific Study of Religion 40(4): 619-36.

Tax, Sol, and Robert Hinshaw. 1970. "Panajachel a Generation Later.” Pp. 175-95 in The Social Anthropology of Latin America: Essay in Honor of Ralph Leon Beals, edited by Walter Goldschmidt and Henry Hoijer. Los Angeles: Latin American Center of the University of California.

Telles, Edward E. 2004. Race in Another America: The Significance of Skin Color in Brazil. Princeton, N.J.: Princeton University Press.

Tomes, Nigel. 1984. "The effects of religion and denomination on earnings and the returns to humancapital," Journal of Human Resources 19(4): 472-488. 
Treisman, Daniel. 2000. "The Causes of Corruption: A Cross-National Study." Journal of Public Economics 76: 399-457.

Trinitapoli, Jenny Ann. 2007. The Role of Religious Organizations in the HIV Criss of Sub-Saharan Africa. Ph.D. dissertation, Sociology Department, University of Texas at Austin.

Turner, Paul. 1979. "Religious Conversion and Community Development." Journal for the Scientific Study of Religion. 18(3): 252-60.

Vingren, Ivar. 1987. Despertamento Apostólico no Brasil Rio de Janeiro: CEPAD.

Wallace, John M., Jr., Tony N. Brown, Jerald G. Bachman and Thomas A. Laveist. 2003. "The Influence of Race and Religion on Abstinence from Alcohol, Cigarettes and Marijuana among Adolescents." Journal of Studies on Alcohol 64: 843-848.

Willems, Emilio. 1967. Followers of the New Faith: Culture Change and the Rise of Protestantism in Brazil and Chile. Nashville: Vanderbilt University Press.

Wolfinger, Nicholas H. 2005. Understanding the Divorce Cycle. New York: Cambridge University Press.

Wolfinger, Nicholas H. and W. Bradford Wilcox. 2008. "Happily Ever After? Religion, Marital Status, Gender, and Relationship Quality in Urban Families." Social Forces. 86(3): 1331-38.

Wood, Charles H., Philip Williams and Kuniko Chijiwa. 2007. "Protestantism and Child Mortality in Northeast Brazil, 2000.” Journal for the Scientific Study of Religion. 46(3): 405-16.

Woodberry, Robert D. 1996. "The Origins of the Temperance Movement: A Comparative Historical Analysis." presented at the national meeting of the American Sociological Association, New York, NY, Aug.

. 2004. The Shadow of Empire: Christian Missions, Colonial Policy and Democracy in PostColonial Societies. Ph.D. dissertation, University of North Carolina, Chapel Hill. . 2008. "Pentecostalism and Economic Development." pp. 157-77 in Markets, Morals, and Religion. Jonathan B. Imber (ed.) with preface by Peter L. Berger. New Brunswick, NJ: Transaction Publishers.

Woodberry, Robert D. and Timothy S. Shah. 2004. "Christianity and Democracy: The Pioneering Protestants." Journal of Democracy 15(2): 47-61.

Zhai, Jiexia Elisa and Robert D. Woodberry. 2011. "Religion and Educational Ideals in Contemporary Taiwan." Journal for the Scientific Study of Religion 50(2): 307-327. 
Table 1. Percent Protestant of the Male Labor Force (15-64 years of age) by Year, 1970-2000

\begin{tabular}{c|c|c|c}
\hline Region & Total Population & Total Protestant & Percent Protestant \\
\hline 1970 & $25,760,600$ & $1,195,292$ & 4.64 \\
1980 & $32,613,947$ & $1,764,415$ & 5.41 \\
1991 & $43,434,546$ & $2,944,862$ & 6.78 \\
2000 & $53,177,953$ & $5,796,397$ & 10.90 \\
\hline
\end{tabular}

Source: 1970-2000 Brazilian Censuses. 
Figure 1. Percent Protestants of the Male Labor Force (15-64 years of age) by Year and MicroRegion, 1970-2000

1970

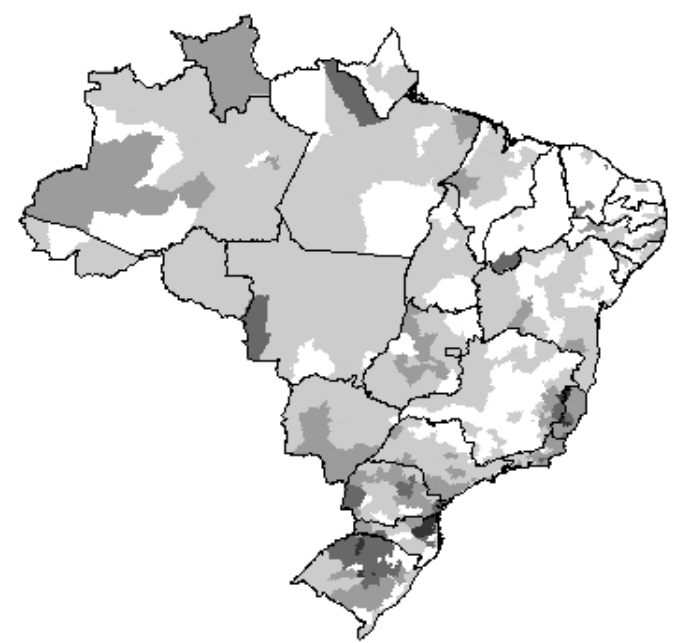

1991

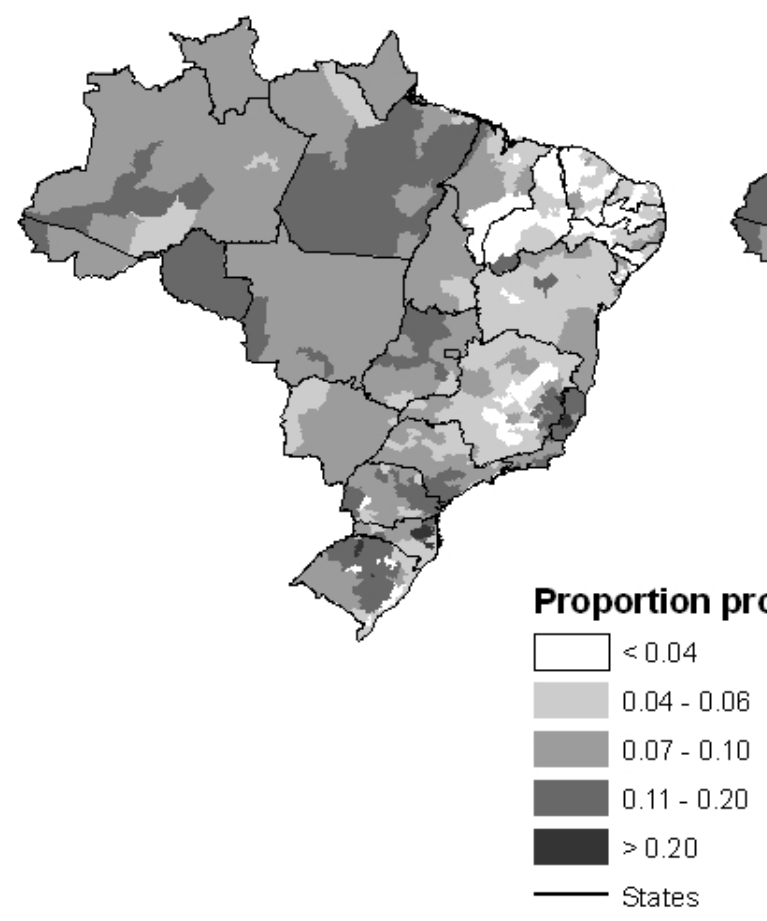

1980

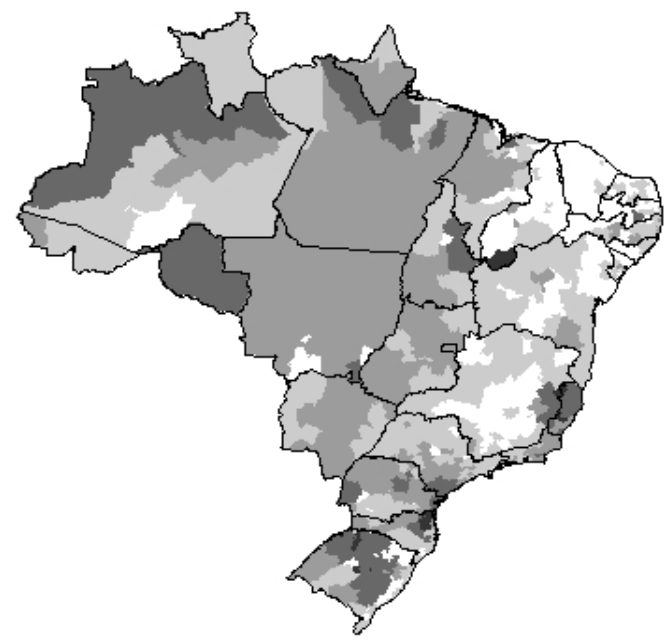

2000

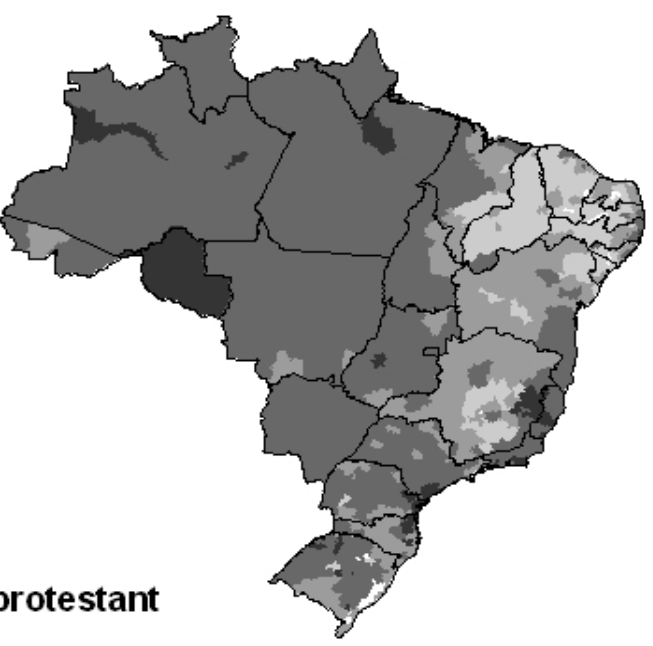

$N$

Source: 1970-2000 Brazilian Censuses. 
Table 2. Percent of Male Population (15-64 years of age) by Year and Age-Education Group, 19702000

\begin{tabular}{l|rrrr}
\hline Age-education Group & $\mathbf{1 9 7 0}$ & $\mathbf{1 9 8 0}$ & $\mathbf{1 9 9 1}$ & $\mathbf{2 0 0 0}$ \\
\hline 15-24 years; 0-4 years of schooling & 28.19 & 20.59 & 14.61 & 9.04 \\
15-24 years; 5-8 years of schooling & 5.38 & 10.53 & 12.09 & 12.46 \\
15-24 years; 9+ years of schooling & 2.74 & 5.87 & 5.97 & 10.24 \\
\hline 25-34 years; 0-4 years of schooling & 19.71 & 16.39 & 12.41 & 8.82 \\
25-34 years; 5-8 years of schooling & 1.98 & 3.90 & 6.82 & 7.63 \\
25-34 years; 9+ years of schooling & 2.00 & 4.77 & 7.40 & 8.12 \\
\hline 35-49 years; 0-4 years of schooling & 22.66 & 19.02 & 17.11 & 13.32 \\
35-49 years; 5-8 years of schooling & 1.62 & 2.39 & 3.67 & 6.73 \\
35-49 years; 9+ years of schooling & 1.59 & 2.84 & 5.54 & 8.46 \\
\hline 50-64 years; 0-4 years of schooling & 12.84 & 11.72 & 11.49 & 10.36 \\
50-64 years; 5-8 years of schooling & 0.65 & 0.94 & 1.16 & 1.99 \\
50-64 years; 9+ years of schooling & 0.62 & 1.05 & 1.72 & 2.84 \\
\hline Total & $\mathbf{2 5 , 7 6 0 , 6 0 0}$ & $\mathbf{3 2 , 6 1 3 , 9 4 7}$ & $\mathbf{4 3 , 4 3 4 , 5 4 6}$ & $\mathbf{5 3 , 1 7 7 , 9 5 3}$ \\
\hline S0ur
\end{tabular}

Source: 1970-2000 Brazilian Censuses. 
Figure 2. Percent Protestant of the Male Labor Force (15-64 years of age) by Year and AgeEducation Group, 1970-2000

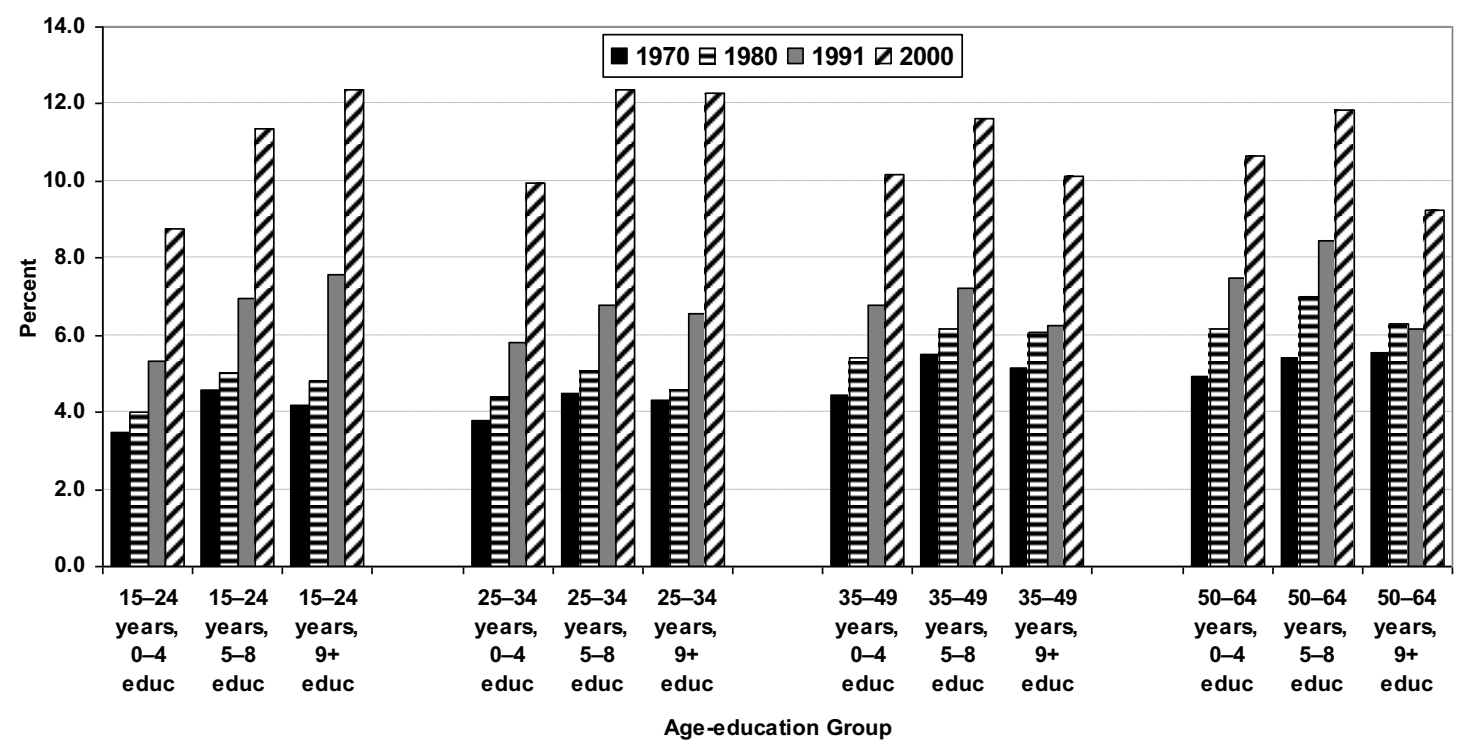

Source: 1970-2000 Brazilian Censuses. 
Figure 3. Mean Real Monthly Earnings of Male Population (15-64 years of age) by Age-Education Group, and Relative Earnings to the 5-8 Education Group for Micro-Regions on the 10th and 90th Percentiles of Protestants, 2000 ${ }^{+}$

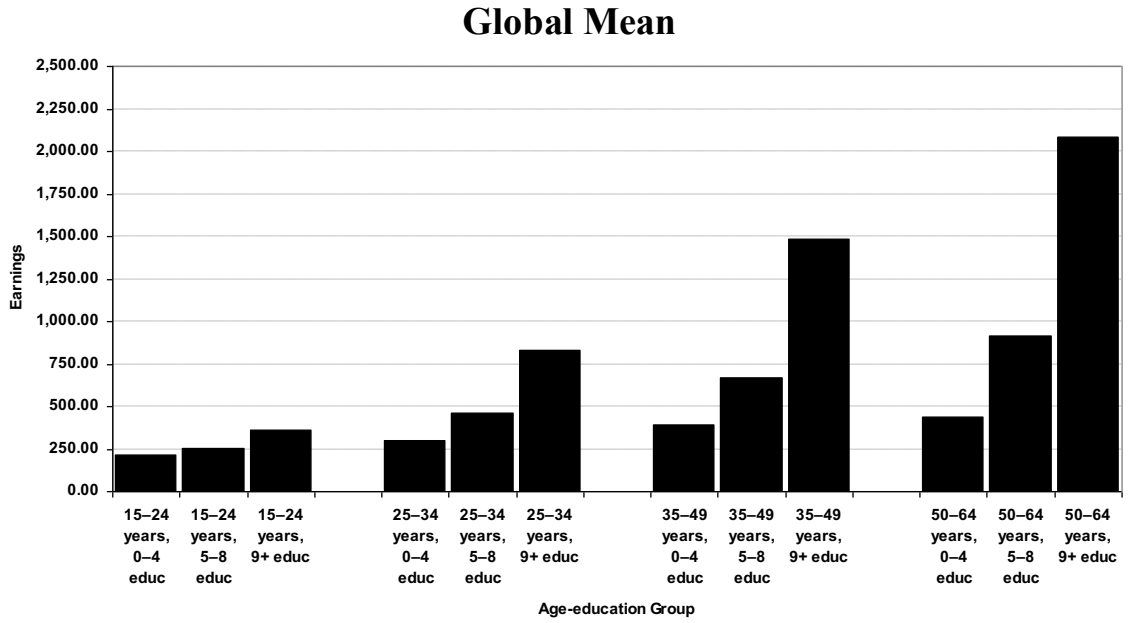

10th Percentile of Protestants

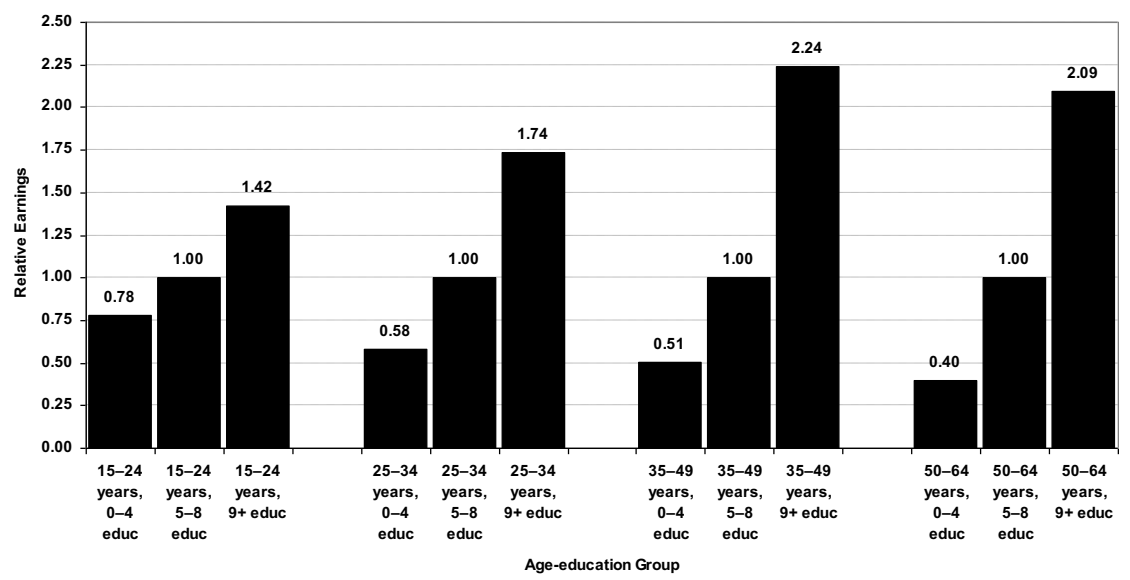

90th Percentile of Protestants

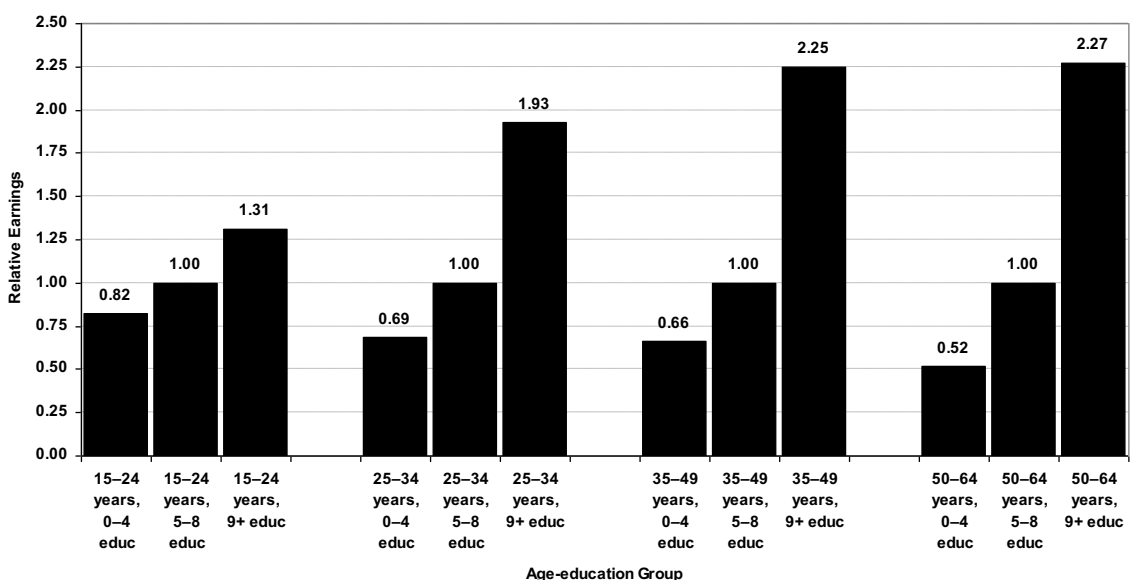

${ }^{+}$Nominal income was converted to base 1 in January 2002, taking into account changes in currency and inflation.

Source: 2000 Brazilian Censuses. 
Table 3. Area and Time Fixed-Effects Estimates of Equation With Age-education Group Indicators, Proportion of Protestants, and Age-education Group Indicators Interacted with Year and Region, 1970-2000. Dependent Variable is $\log \left(\right.$ Monthly Earnings) ${ }^{+}$

\begin{tabular}{l|r}
\hline \multicolumn{1}{c|}{ Proportion of Protestants } & Coefficients $^{++}$ \\
\hline Ages 15-24 years; 0-4 years of schooling & $0.663^{* * *}$ \\
& $(0.1131)$ \\
Ages 15-24 years; 5-8 years of schooling & $0.304^{* *}$ \\
Ages 15-24 years; 9+ years of schooling & $(0.1053)$ \\
$0.202^{*}$ \\
\hline Ages 25-34 years; 0-4 years of schooling & $(0.0906)$ \\
Ages 25-34 years; 5-8 years of schooling & $0.609^{* * *}$ \\
& $(0.1029)$ \\
Ages 25-34 years; 9+ years of schooling & 0.080 \\
\hline Ages 35-49 years; 0-4 years of schooling & $(0.0991)$ \\
& $0.223^{*}$ \\
Ages 35-49 years; 5-8 years of schooling & $(0.0977)$ \\
Ages 35-49 years; 9+ years of schooling & $0.694^{* * *}$ \\
\hline Ages 50-64 years; 0-4 years of schooling & $(0.0987)$ \\
& -0.027 \\
Ages 50-64 years; 5-8 years of schooling & $(0.1026)$ \\
& $0.207^{*}$ \\
Ages 50-64 years; 9+ years of schooling & $(0.1047)$ \\
\hline
\end{tabular}

\begin{tabular}{l|c}
\hline N observations & 19,727 \\
$\mathrm{~N}$ groups & 2,008 \\
\hline Rho: Fraction of variance due to the $v_{i}$ & 0.8275 \\
\hline F-test $\left(\right.$ all $\left.\varepsilon_{i}=0\right):$ & $\mathrm{F}(232 ; 17,487):$ \\
All coefficients $=0$ & $1,214.12 * * *$ \\
\hline F-test $\left(\right.$ all $\left.v_{i}=0\right):$ & $12.32 * * *$ \\
Area/time fixed effects $=0$ & 0.9415 \\
$\mathrm{R}^{2}$ (within) & 0.6385 \\
$\mathrm{R}^{2}$ (between) & 0.7809 \\
$\mathrm{R}^{2}$ (overall) & \\
\hline
\end{tabular}

\footnotetext{
* Significant at $\mathrm{p}<.05 ; * *$ Significant at $\mathrm{p}<.01 ; * * *$ Significant at $\mathrm{p}<.001$.

${ }^{+}$Nominal income was converted to base 1 in January 2002, taking into account changes in currency and inflation.

+ Coefficients from constant, age-education group indicators, and age-education group indicators interacted with year and region are not displayed in this table.

Source: 1970-2000 Brazilian Censuses.
} 
Figure 4. Distribution of Non-Whites of the Male Labor Force (15-64 years of age) by Education Group and Micro-Region, 2000

\section{0-4 years of education $\quad 5-8$ years of education}
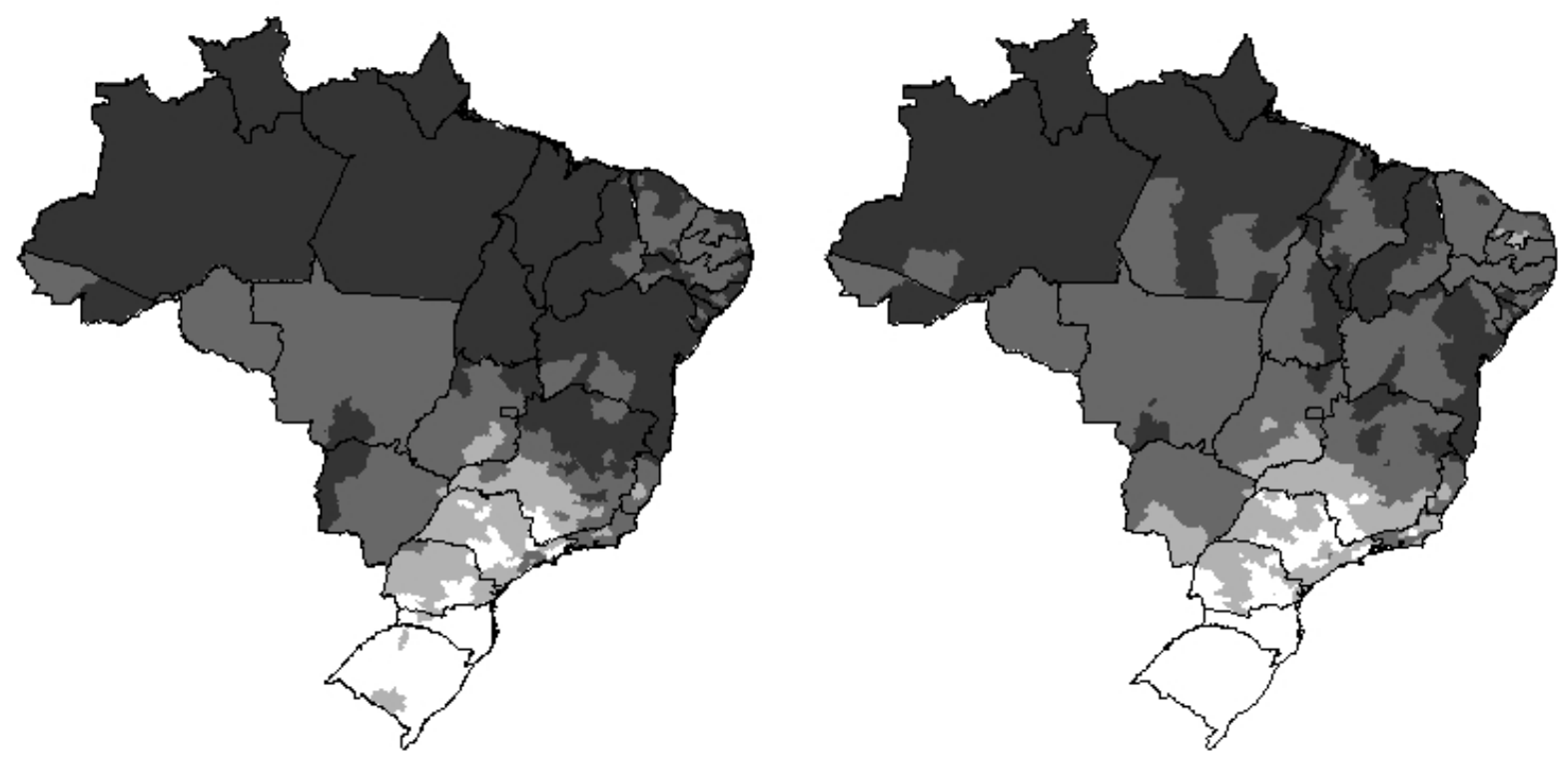

\section{$9+$ years of education}
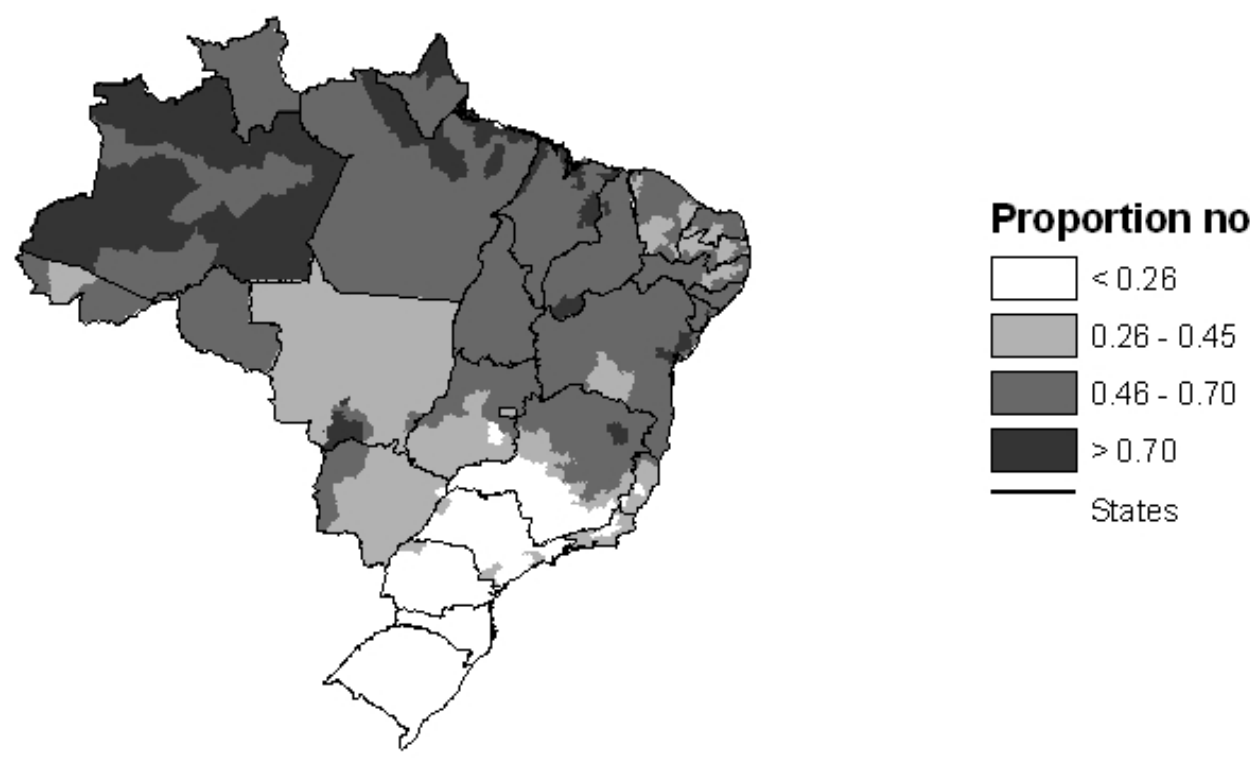

Source: 2000 Brazilian Census. 
Table 4. Area and Time Fixed-Effects Estimates of Equation With Age-education Group Indicators, Proportion of Protestants, Proportion of Non-Whites, Age-education Group Indicators Interacted with Year and Region, and Proportion of Protestants Interacted with Proportion of Non-Whites, 1980-2000. Dependent Variable is $\log \left(\right.$ Monthly Earnings ${ }^{+}$

\begin{tabular}{|c|c|c|c|}
\hline Coefficients $^{++}$ & $\begin{array}{l}\text { Proportion } \\
\text { Protestant }\end{array}$ & $\begin{array}{c}\text { Proportion } \\
\text { of Non-Whites }\end{array}$ & $\begin{array}{l}\text { Protestant } \\
* \text { Non-White }\end{array}$ \\
\hline $\begin{array}{l}\text { Ages } 15-24 \text { years; } \\
0-4 \text { years of schooling }\end{array}$ & $\begin{array}{r}-0.035 \\
(0.2492)\end{array}$ & $\begin{array}{r}-0.787 * * * \\
(0.0581)\end{array}$ & $\begin{array}{r}0.918 \\
(0.4784)\end{array}$ \\
\hline $\begin{array}{l}\text { Ages } 25-34 \text { years; } \\
0-4 \text { years of schooling }\end{array}$ & $\begin{array}{r}-0.003 \\
(0.2174)\end{array}$ & $\begin{array}{r}-0.879 * * * \\
(0.0575)\end{array}$ & $\begin{array}{r}1.041^{*} \\
(0.4369)\end{array}$ \\
\hline $\begin{array}{l}\text { Ages } 35-49 \text { years; } \\
0-4 \text { years of schooling }\end{array}$ & $\begin{array}{r}-0.011 \\
(0.1986)\end{array}$ & $\begin{array}{r}-0.950 * * * \\
(0.0583)\end{array}$ & $\begin{array}{l}1.463 * * \\
(0.4230)\end{array}$ \\
\hline $\begin{array}{l}\text { Ages } 50-64 \text { years; } \\
0-4 \text { years of schooling }\end{array}$ & $\begin{array}{r}-0.158 \\
(0.1757) \\
\end{array}$ & $\begin{array}{r}-0.967 * * * \\
(0.0565) \\
\end{array}$ & $\begin{array}{r}1.528 * * * \\
(0.3765) \\
\end{array}$ \\
\hline $\mathrm{N}$ observations & 15,669 & & \\
\hline $\mathrm{N}$ groups & 1,506 & & \\
\hline $\begin{array}{l}\text { Rho: } \\
\text { Fraction of variance due to the } v_{i}\end{array}$ & 0.7426 & & \\
\hline $\begin{array}{l}\text { F-test }\left(\text { all } \varepsilon_{\mathrm{i}}=0\right): \\
\text { All coefficients }=0\end{array}$ & $\begin{array}{r}\mathrm{F}(201 ; 13,962): \\
1,047.00 * * *\end{array}$ & & \\
\hline $\begin{array}{l}\text { F-test }\left(\text { all } v_{\mathrm{i}}=0\right): \\
\text { Area/time fixed effects }=0\end{array}$ & $\begin{array}{r}\mathrm{F}(1,505 ; 13,962): \\
11.01 * * * \\
\end{array}$ & & \\
\hline $\mathrm{R}^{2}$ (within) & 0.9378 & & \\
\hline $\mathrm{R}^{2}$ (between) & 0.5898 & & \\
\hline $\mathrm{R}^{2}$ (overall) & 0.8255 & & \\
\hline
\end{tabular}

* Significant at $\mathrm{p}<.05 ; * *$ Significant at $\mathrm{p}<.01 ; * * *$ Significant at $\mathrm{p}<.001$.

${ }^{+}$Nominal income was converted to base 1 in January 2002, taking into account changes in currency and inflation.

${ }^{++}$Coefficients from constant, age-education group indicators, age-education group indicators interacted with year and region, and age-education groups with 5-8 and 9+ years of schooling are not displayed in this table.

Source: 1980-2000 Brazilian Censuses. 
Figure 5. Predicted Relative Earnings of Males with 0-4 Years of Schooling for Various Proportions Non-White and Proportions Protestant in Each Age Group, Brazil, 1980-2000
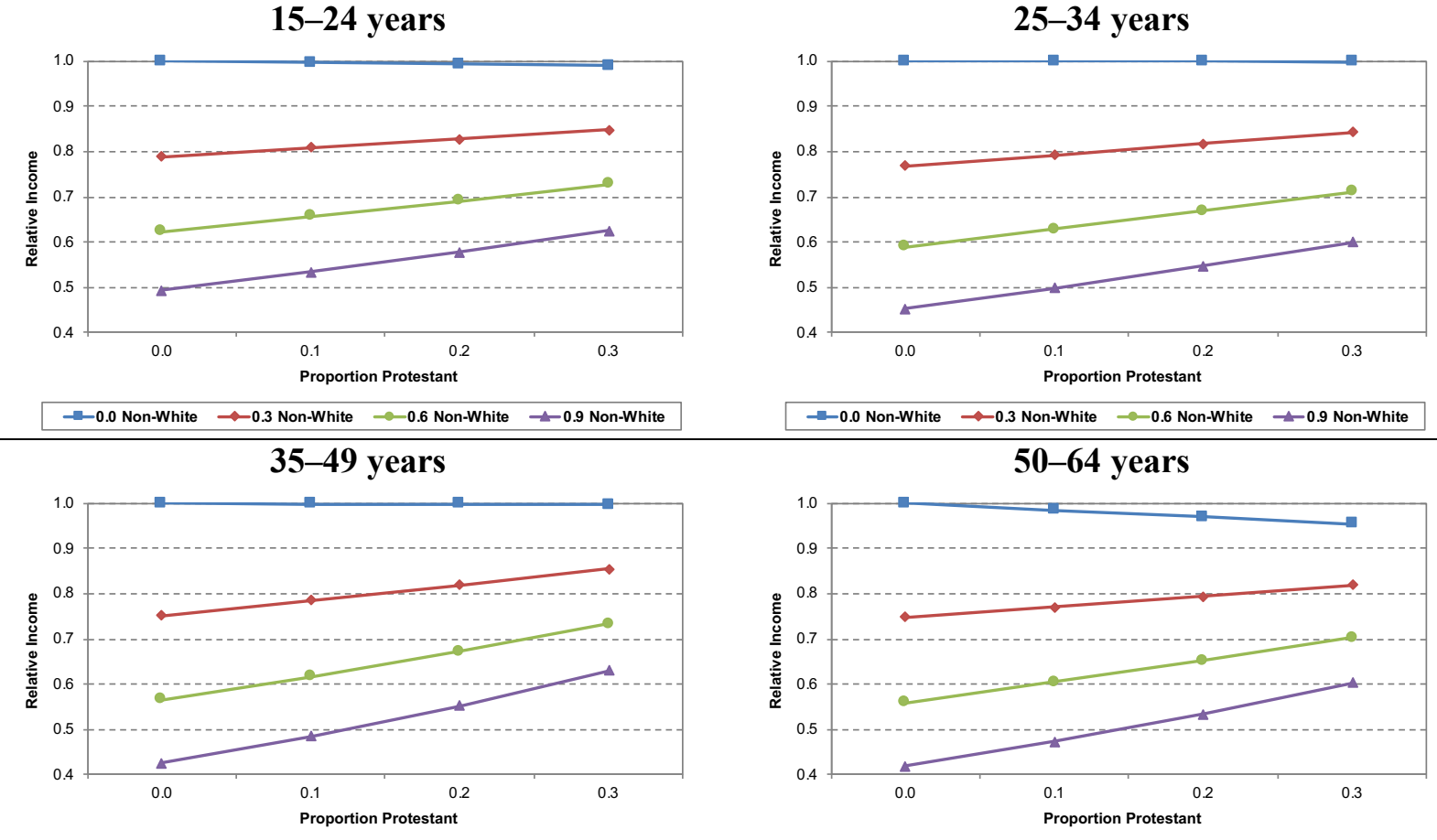

$\rightarrow 0.0$ Non-White $\rightarrow 0.3$ Non-White $\rightarrow 0.6$ Non-White $\rightarrow 0.9$ Non-White

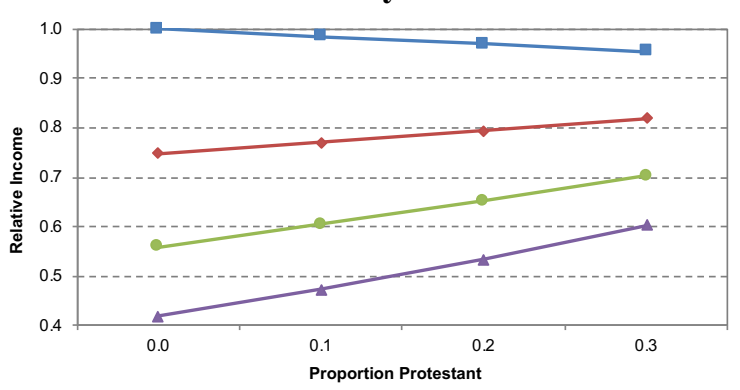

Source: 1980-2000 Brazilian Censuses. 